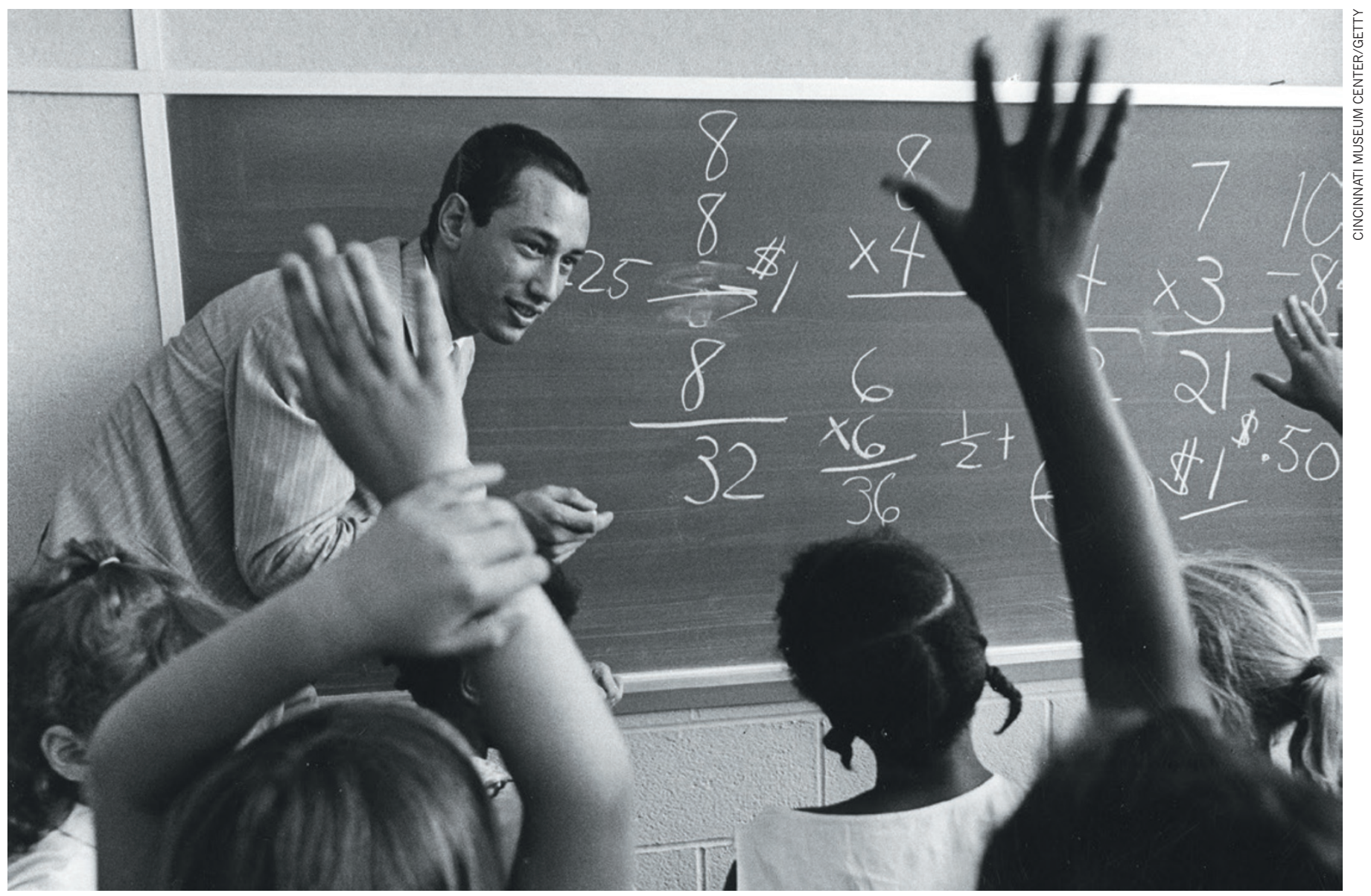

US maths education was kicked into space-age overdrive by the launch of the Soviet Sputnik satellite.

\title{
Set theory for six-year-olds
}

\section{Alex Bellos savours a history of the 'new math' that swept US schools in the 1960s.}

$\mathrm{I}$ $\mathrm{t}$ was hailed as a revolutionary mathematics curriculum that prioritized the concept of a set over the concept of a number. 'New math' was introduced to millions of US schoolchildren in the 1960s. Yet in less than a decade it was being lampooned unforgettably by the mathematician and satirist Tom Lehrer. The refrain of his song 'New Math' is: "It's so simple, so very simple, that only a child can do it!"

Teaching set theory to six-year-olds as a way into mathematics, from arithmetic on, would come to be considered misguided, overcomplicating the basics and introducing jargon. Yet however radical a shift it represented, the new math was not a liberal experiment. It was, writes science historian Christopher Phillips in The New Math, an essentially conservative cold-war initiative. In 1957, the Soviet Union launched Sputnik, the first Earth-orbiting satellite. The United States was spooked (and

not for the last time) by the risk of falling behind in science, leading to a political consensus that maths teaching needed to be reformed to produce students with sharper cognitive skills.

As Phillips explains, rather than starting a maths class by learning to count, children were asked to think about sets of objects,

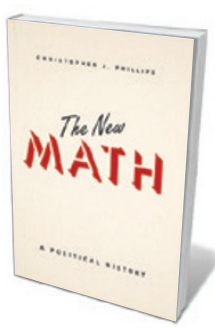

The New Math: A Political History CHRISTOPHER J, PHILLIPS

University of Chicago Press: 2014 introduced, as the property shared by equivalent sets, represented by a symbol called a numeral. The number 1 , for example, was precisely that which all sets with a single member had in common.

The New Math charts the method's rise and fall through the story of the School Mathematics Study Group (SMSG), an association of mathematicians and teachers formed in early 1958 and funded by the US National Science Foundation. Awash with money, the SMSG came up with progressive new ideas for "how mathematics could and should cultivate mental habits"; this, Phillips writes, is "the only reform effort that rooted federal money directly and explicitly in claims about how students should learn to think". The SMSG concluded that maths lessons should be less about number crunching and more about abstract thinking. A tension between rote learning and puzzle-solving lies at the heart of maths 
pedagogy, but never has practice swung so far from arithmetic drills as during the newmath era. The SMSG's textbook for junior high schools began, for example, with the story of a mathematician on a plane telling his neighbour that counting with numbers is best done by machines and that his job is "logical reasoning".

One reason for the SMSG favouring abstraction over calculation was that it was led by professional mathematicians, not teachers. Many were deeply influenced by Nicolas Bourbaki, the pseudonym for a group of ideological French mathematicians of the 1930s who argued that mathematics was about structure, and that set theory underlay the structure of numbers. 'Modern' maths, argued the SMSG, was needed for space-age science.

New math was a voluntary programme, and in terms of take-up it was a huge success. By 1965 , it was estimated, nearly $75 \%$ of US high-school pupils and $40 \%$ of elementaryschool pupils were studying a version of it; a decade later, it was still taught in an estimated $85 \%$ of schools. Major educational publishers sold millions of books influenced by the SMSG's ideas. But the backlash, which had started in the early 1960s, had become fierce by the 1970s. And as Phillips points out, the reasons were as much to do with politics as with pedagogy.

Phillips notes the irony of a nationalistic, cold-war-inspired project introduced to promote rigorous thinking becoming the target of conservatives less than two decades later, partly because they claimed that it failed to impart mental rigour. The 1970s 'back to basics' movement - a decentralized collection of vocal parents horrified at the lack of memorization drills - echoed broader political shifts. People were less inclined to accept diktats from elite authorities such as Washington DC politicians and Ivy League academics. The new math was criticized, possibly unfairly, for declining test scores, rowdy classrooms and children's poor computational skills, and its name became a byword for crazy progressive reforms. The SMSG shut down in 1972, although many schools that had invested in new math had to keep using the same textbooks until the end of the 1970s and beyond. (By then, the method had spread around the world. I was taught set theory at primary school in Scotland in the late 1970s.)

Phillips reminds us in his fascinating book that even though mathematics is supposed to be apolitical, the teaching of it is anything but.

Alex Bellos is the author of Alex Through the Looking-Glass (US title: The Grapes of Math). He is based in London.

e-mail:alexanderbellos@gmail.com

\section{Books in brief}

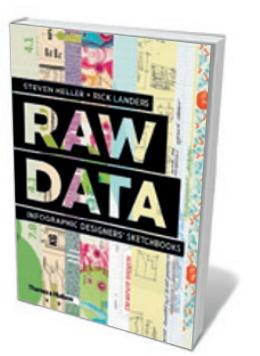

Raw Data: Infographic Designers' Sketchbooks

Steven Heller and Rick Landers THAMES AND HUDSON (2014)

An artist's sketchbook is a peek at cognition's wilder shores: the on-the-fly observations and dogged experimentation that feed the final picture. In this splendid compilation, Steven Heller and Rick Landers riffle through the pages of 73 infographic artists - the wizards who translate numbers into graphics. Juxtaposing doodles with smooth finales, the book explores the work of stars such as Nigel Holmes, whose 'meat and two veg' head reworks the food pyramid in wacky homage to the 'cornucopia' portraits of sixteenthcentury artist Giuseppe Arcimboldo.

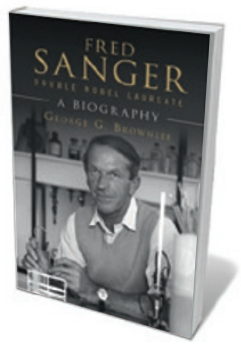

Fred Sanger - Double Nobel Laureate: A Biography

George G. Brownlee CAMBRIDGE UNIVERSITY PRESS (2014)

The biochemist Frederick Sanger, whose DNA sequencing method made the Human Genome Project possible, died last year. One of only four scientists to win two Nobel prizes, Sanger is revealed in this slim biography by George Brownlee (who studied under him) as inherently modest about his landmark achievements in protein and DNA sequencing. Included are a revealing and fascinating 1992 interview with Sanger that elucidates how he hit on his discoveries, and encomia from the likes of fellow laureates Paul Berg, Elizabeth Blackburn and Paul Nurse.

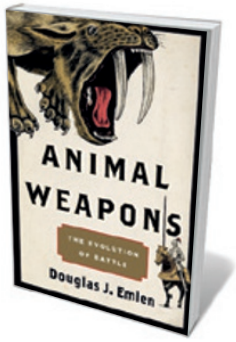

\section{Animal Weapons: The Evolution of Battle}

Douglas J. Emlen HENRY HOLT (2014)

It began with dung beetles. Evolutionary biologist Douglas Emlen's self-confessed fixation on 'extreme' animal weapons was first channelled into research on these horned insects. In this original study, Emlen tours offensive and defensive anatomy and behaviours across aeons and taxa, from Tyrannosaurus rex's fearsome teeth to ibex horns and amphibian poisons. He sharpens the discussion by interweaving parallels with humanity's own evolving arsenal, including weapons of mass destruction - the most extreme of all arms, which if deployed cancel out the very concept of battle.

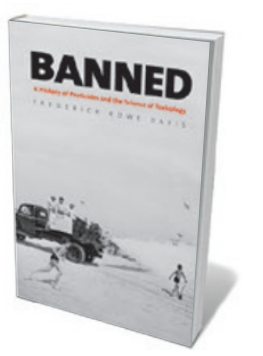

Banned: A History of Pesticides and the Science of Toxicology Frederick Rowe Davis YALE UNIVERSITY PRESS (2014)

Historian Frederick Davis takes on the ambitious task of writing the history of pesticides before and in the wake of Rachel Carson's iconic 1962 book Silent Spring. In a treatment dense with references, acronyms, chemical names and technical discussions of lethal doses, Davis offers a keen historical perspective on the compounds that big agriculture has used to keep bugs at bay. He forms a scholarly indictment of a system that heeded Carson's superficial message in banning DDT, but ignored her underlying warning that existing systems for managing pesticides are often inadequate.

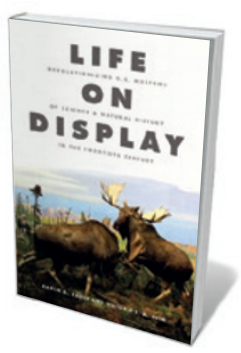

Life on Display: Revolutionizing U.S. Museums of Science and Natural History in the Twentieth Century

Karen A. Rader and Victoria E. M. Cain UNIVERSITY OF CHICAGO PRESS (2014) The exquisite dioramas in New York's American Museum of Natural History have wowed crowds since the early twentieth century. But as historians Karen Rader and Victoria Cain reveal in this cogent study, they were part of a broader revolution: the "New Museum Idea", which saw "smell machines" and dynamic models supersede dusty cases. The behind-the-scene struggles between 'edutainers' and serious museum researchers were, they show, no less dynamic. Barbara Kiser 